\title{
Behaviors and Trends toward Routine Maintenance and Major Repairs of Afridev Handpumps in Rural Malawi
}

\author{
Jonathan P. Truslove ${ }^{1,2}$, Andrea B. Coulson ${ }^{3} \mathbb{D}$, Emma Mbalame ${ }^{4}$ and Robert M. Kalin ${ }^{1, *(D)}$ \\ 1 Department of Civil and Environmental Engineering, University of Strathclyde, Glasgow G1 1XJ, UK; \\ jonathan.truslove@ewb-uk.org \\ 2 Engineers Without Borders UK, The Foundry, 17 Oval Way, London SE11 5RR, UK \\ 3 Department of Accounting and Finance, University of Strathclyde, Glasgow G4 0QU, UK; \\ a.b.coulson@strath.ac.uk \\ 4 Department Water Supply, Ministry of Forestry and Natural Resources, Lilongwe, Malawi; \\ emmambalame5@gmail.com \\ * Correspondence: Robert.Kalin@strath.ac.uk
}

check for updates

Citation: Truslove, J.P.; Coulson,

A.B.; Mbalame, E.; Kalin, R.M.

Behaviors and Trends toward Routine Maintenance and Major Repairs of Afridev Handpumps in Rural Malawi. Water 2021, 13, 1666. https: / / doi.org/10.3390/w13121666

Academic Editor: Stefano Alvisi

Received: 26 April 2021

Accepted: 11 June 2021

Published: 15 June 2021

Publisher's Note: MDPI stays neutral with regard to jurisdictional claims in published maps and institutional affiliations.

Copyright: (c) 2021 by the authors. Licensee MDPI, Basel, Switzerland. This article is an open access article distributed under the terms and conditions of the Creative Commons Attribution (CC BY) license (https:/ / creativecommons.org/licenses/by/ $4.0 /)$.

\begin{abstract}
Service provision for Afridev handpumps through community management in Malawi is a notable challenge. Essential preventative maintenance is often neglected, and repairs are undertaken on a reactive basis. The costs of major repairs are not recognized at community level and are typically neglected across the lifecycle of infrastructure or left to external stakeholders. The aim of this study was to investigate preventative maintenance and capital maintenance expenditure over the 15-year design lifecycle of 21,997 Afridev handpumps in Malawi, and how costs change based on different local tariff collection scenarios. A total of four tariff collection scenarios were investigated, for assets both subject and not subject to rehabilitation. The findings highlight poor initial capacity building into appropriate cost recovery and maintenance approaches. Major repair costs increase over the pump lifecycle when service consists of the replacement of low-cost, fast-wearing parts. Rehabilitation/major repair costs increase as a result but tend to be focused on simple longer-life components, such as pump rods. In both cases, a reliance on external support was highlighted, as larger costs are primarily covered by donors and Non-Governmental Organisations (NGOs). Proactive tariff scenarios may provide a greater capability of replacement throughout the lifecycle of major items when compared to reactive tariff scenarios. It is recommended that policy and practitioners should focus on capacity building of sustainable maintenance models that consider the full lifecycle costs of assets.
\end{abstract}

Keywords: rural water supply; community-based management; Afridev handpump; capital maintenance; Malawi; preventative maintenance; rural water tariff; lifecycle assessment

\section{Introduction}

The delivery of sustainable rural water services requires appropriate financial and maintenance approaches to sustain and repair an asset across its lifecycle [1,2]. While investment into new infrastructure and rehabilitation programs has increased the global coverage of improved water supply [3-6], capacity building and lifecycle assessments to sustain such services have been lacking $[1,7,8]$. This focus on capital expenditure (CapEx) has led to impulsive investment, with limited comprehensive planning into the additional costs required for long-term sustainability of the water supply [9].

The community-based management (CBM) approach emerged in the 1990s in many developing countries (including Malawi, where CBM is embedded in national policy) as a decentralized model for service delivery and management of rural water supplies. It proclaimed "community empowerment" [10] while relieving responsibilities from central governments and external donor support [11,12]. The well-acknowledged limitations of this one-size-fits-all approach showed that the promotion of CBM was "a triumph of 
hope over realism" [13]. Communities have shown that they are capable of dealing with basic maintenance when professionalism and post-construction support are present $[14,15]$. However, the implementation of technologies that require regular maintenance, such as handpumps, means asset management technical knowledge is often beyond communities' capabilities [16,17]. The maintenance that is conducted often occurs on a reactive basis (through trained government or private technical service providers such as area mechanics or borehole mechanics), and assets become stranded (not in use) when just one component fails $[2,18]$. The replacement of components before they fail through preventative and timely maintenance is crucial for the continued serviceability of handpumps, reducing the cost of premature failure [19-22]. This is often not completed and perceived to be a redundant exercise by communities [23-25].

The cost recovery mechanism to fund operations and maintenance (O\&M) activities is primarily accomplished through tariffs in the form of household contributions [26]. The collection of these financial contributions may be insufficient for crucial non-routine maintenance to prevent service deterioration [27-29]. Furthermore, long-term maintenance is often left to stakeholders outside the community, such as local or national governments, NGOs, or donors [17]. The resulting maintenance budgets for long-term management are therefore based on forward financial or budgetary projections and not site-specific needs assessments.

Figure 1 provides a conceptual representation of an Afridev handpump installation showing the fast-wearing parts described later in this paper (generally costed through $\mathrm{O} \& \mathrm{M})$ and design-life timeline that requires financial planning to maintain and rehabilitate.
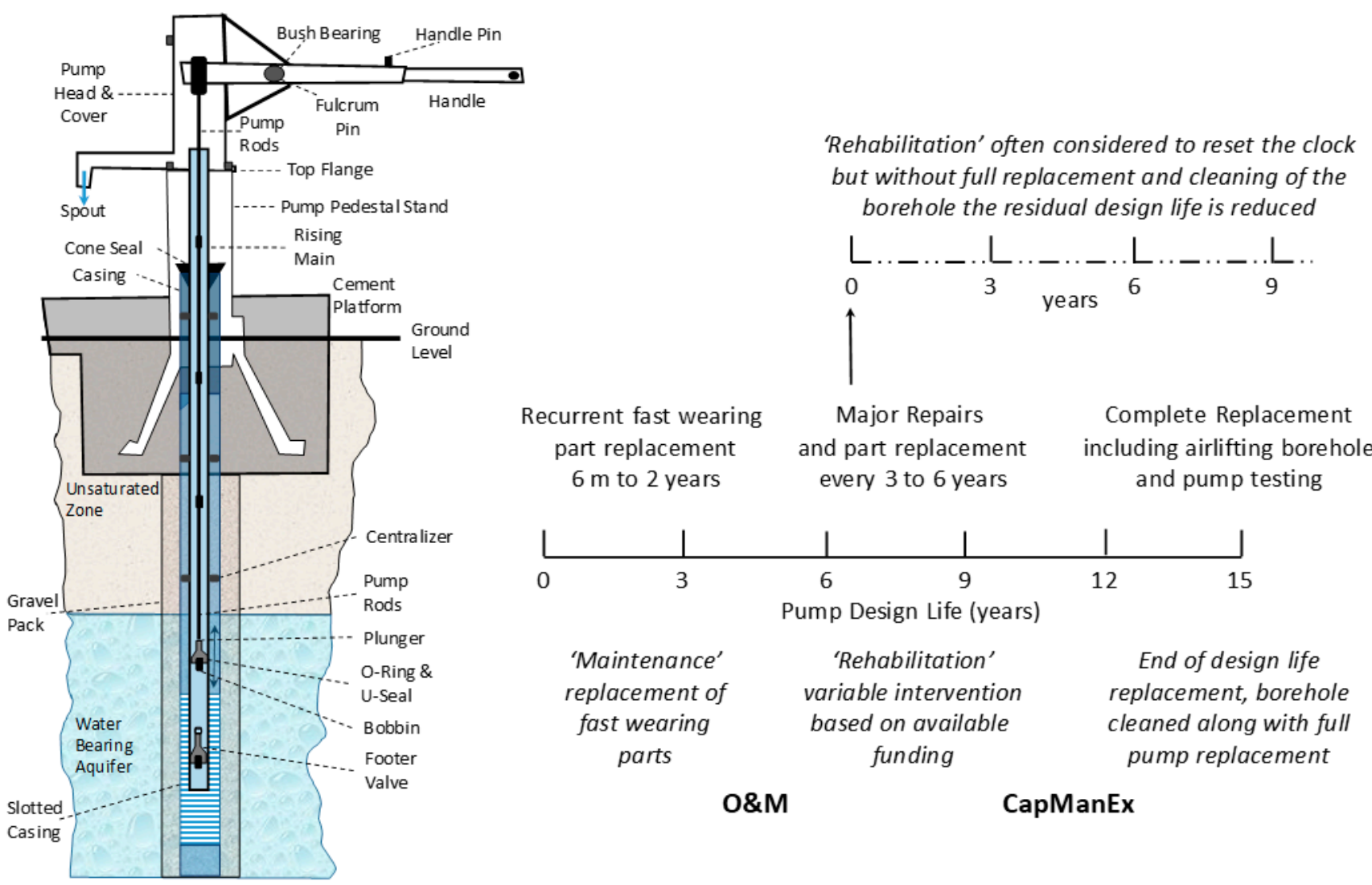

Figure 1. Generalized diagram of the Afridev handpump lifecycle indicating wearing parts and approximate design-life timeline of key maintenance concepts.

Capital maintenance expenditure (CapManEx) describes the costs of sustaining or renewing an existing service [18]. Whether routine maintenance includes CapManEx is a 
matter of the required frequency for replacement and cost [18]. Site-specific challenges (e.g., aggressive water chemistry that corrodes parts such as the pump stand and cement, or iron bacteria blooms reducing water flow in the borehole) result in variable CapManEx, which in turn will result in differences in site-specific costs between communities. CapManEx costs are therefore not widely understood by local and national governments and are not separated in budget planning [30], and they should be the focus of the forensic analysis of all water points [2]. In addition, the complete replacement of pump infrastructure along with borehole rehabilitation (airlifting to remove sediment and possible treatments to chemically remove clogging agents) is extremely rare, even though it is a known requirement [2]. In most cases, NGOs and governments allocate rehabilitation budgets at the time of failure rather than planning for the CapManEx and budgeting for sustainability [30]. As a result, CapManEx is overlooked and under-resourced, resulting in failure of supply, abandonment, and reduced design life, producing stranded assets $[2,13,16,17]$.

While outside the scope of this infrastructure-related study, it is recognized that water quality monitoring budgeting is important (microbiological and chemical) and is a crucial aspect affecting the costs of routine maintenance and CapManEx. However, the costs of these are for the most part omitted within tariffs and rehabilitation budgeting. In areas of Malawi, occurrences of arsenic, fluoride, salinity, and microbial contaminant (Escherichia coli) have a notable impact on the suitability and sustainability of rural groundwater supplies and infrastructure [2,31-37]. Water quality and the costs of site-specific monitoring and remedial actions need to be added to the wider lifecycle costs (O\&M and CapManEx).

The aim of this study was to investigate preventative O\&M and CapManEx over the 15-year lifecycle of the Afridev handpump and how these change with different local tariff collection scenarios. Data for CBM-based service providers for boreholes equipped with Afridev handpumps were examined from a large and recent dataset. Major repairs that were conducted within a 1-year window were investigated through a 15-year period in line with the expected design life (Figure 1), including the costs, stakeholders conducting repairs, and components replaced. These data were interrogated for assets that have been rehabilitated and assets that have not.

\section{Materials and Methods}

This paper draws upon data associated with the service provision, O\&M, and CapManEx domains for drilled boreholes equipped with Afridev handpumps installed during the period of 2000 to 2019 in Malawi. Data collection by the Government of Malawi took place as part of the Climate Justice Fund (CJF) Water Futures research program evaluating the sustainability of rural and periurban water supplies in Malawi [2] (full survey provided in the Supplementary Material). Improved and unimproved surface- and groundwater supply assets $(\mathrm{n}=124,030)$ were evaluated by the Government of Malawi across the country using the management information system (MIS) mWater (www.mwater.co, accessed on 26 April 2021). Data were collected by Government of Malawi staff through a water point functionality survey based on sustainability indicators and additional needs of the Malawian government (Supplementary Materials). Data on assets up to the design limit of 15 years old were selected. If rehabilitation exercises had been conducted, the age of the Afridev was reset to the date of rehabilitation as if it were a new asset (standard practice in Malawi).

Service providers under the CBM model, Water Point Committees (WPC), area mechanics (AM), community members, and combinations of the prior were determined. This resulted in a dataset of 21,997 boreholes equipped with Afridev handpumps that offered full complementarity of information. These data were subdivided into four scenarios, investigated based on tariff collection frequency:

(1) Scenario A defines water tariffs collected "per month";

(2) Scenario B defines water tariffs collected "when required for repairs";

(3) Scenario C defines water tariffs collected "per year"; and

(4) Scenario D defines "no tariff" collected (recovered costs unrelated to water usage). 
Under these scenarios, the behaviors toward preventative maintenance were highlighted from the dataset. Where no preventative maintenance was conducted, the reasons were investigated. Data associated with CapManEx were highlighted if "major repairs had been conducted in the last year", which concerns repairs costing approximately MWK 50,000 or more (where USD $1=$ MWK 790, as of April 2021). The distribution of costs was investigated over the design limit of the Afridev alongside the stakeholders who conducted such repairs by each scenario in each cost category. The components replaced during major repairs were also investigated by each scenario, with a focus on rod replacements over the duration of the Afridev lifecycle. These data were subdivided into assets without rehabilitation and those that had been rehabilitated (where a rehabilitation exercise consists of a single repair costing more than MWK 1,500,000):

Routine Maintenance, spare parts (assumed MWK $<50,000$ );

Major Repair, single replacements (assumed MKW > 50,000);

"Rehabilitation", multiple part replacements (assumed MKW > 1,500,000).

The resulting data underwent statistical analysis using the functions available within the software package Microsoft ${ }^{\mathrm{TM}} \mathrm{Excel}^{\mathrm{TM}}$, and the resulting graphs and heat maps were produced with the same software.

\section{Results}

\subsection{Behaviors toward Preventative Maintenance}

Each service provider for the Afridev is responsible for the preventative maintenance of the handpump and is therefore entitled to receive regular training from the supplier [38]. However, preventative maintenance can feel like a redundant exercise [23-25], and continued support for rural communities is lacking under CBM. Table 1 presents the breakdown of preventative maintenance conducted across the scenarios specified from our data, including explanations as to why preventative maintenance was not conducted.

Table 1. Preventative maintenance conducted in each scenario $(n=21,997)$ : Yes $=$ preventative maintenance was conducted, No = preventative maintenance was not conducted, Sometimes $=$ no predictable maintenance planning.

\begin{tabular}{|c|c|c|c|c|c|c|c|c|}
\hline \multirow[t]{2}{*}{ Variable } & \multicolumn{2}{|c|}{ Scenario A } & \multicolumn{2}{|c|}{ Scenario B } & \multicolumn{2}{|c|}{ Scenario C } & \multicolumn{2}{|c|}{ Scenario D } \\
\hline & $\mathrm{n}$ & $\%$ & $\mathrm{n}$ & $\%$ & $\mathrm{n}$ & $\%$ & $\mathrm{n}$ & $\%$ \\
\hline Yes & 7747 & 79.8 & 3427 & 72.4 & 3176 & 79.8 & 1863 & 52.0 \\
\hline Sometimes & 504 & 5.2 & 316 & 6.7 & 184 & 4.6 & 296 & 8.2 \\
\hline No & 1456 & 15.0 & 986 & 20.9 & 616 & 15.5 & 1426 & 39.8 \\
\hline \multicolumn{9}{|c|}{ Why preventative maintenance is not conducted $(n=5194)^{1}$} \\
\hline & $\mathrm{n}$ & $\%$ & $\mathrm{n}$ & $\%$ & $\mathrm{n}$ & $\%$ & $\mathrm{n}$ & $\%$ \\
\hline Lack of money & 214 & 12.9 & 280 & 23.3 & 56 & 8.3 & 303 & 18.3 \\
\hline $\begin{array}{l}\text { Lack of technical } \\
\text { expertise }\end{array}$ & 766 & 46.1 & 381 & 31.7 & 375 & 55.7 & 441 & 26.6 \\
\hline Parts not available & 52 & 3.1 & 57 & 4.7 & 37 & 5.5 & 84 & 5.1 \\
\hline Lack of understanding & 422 & 25.4 & 412 & 34.3 & 120 & 17.8 & 550 & 33.2 \\
\hline Newly Constructed & 113 & 2.2 & 13 & 0.3 & 31 & 0.6 & 96 & 1.9 \\
\hline $\begin{array}{l}\text { No experienced } \\
\text { breakdown }\end{array}$ & 48 & 0.9 & 26 & 0.5 & 30 & 0.6 & 70 & 1.4 \\
\hline No training & 9 & 0.2 & 7 & 0.1 & 6 & 0.1 & 30 & 0.6 \\
\hline Non-functional & 0 & 0.0 & 1 & 0.1 & 0 & 0.00 & 32 & 0.6 \\
\hline Other & 17 & 0.3 & 15 & 0.3 & 10 & 0.2 & 31 & 0.6 \\
\hline Don't know & 20 & 1.2 & 10 & 0.8 & 8 & 1.2 & 21 & 1.3 \\
\hline
\end{tabular}

${ }^{1}$ Respondents can provide more than one answer as to why preventative maintenance is not conducted.

Scenarios with tariff $(\mathrm{A}, \mathrm{B}, \mathrm{C})$ funds available show a significant percentage of the reported cases conducting preventative maintenance compared to those with no tariff (D). This suggests that the presence of financial resources has a positive influence on the ability 
to conduct maintenance, as preventative or timely reactive maintenance can reduce the costs of premature failure and downtime of services [17].

The question of why preventative maintenance is not conducted, then, further highlights a lack of initial and continued support for service providers under the CBM model, with our data indicating "lack of technical expertise" and "lack of understanding" as the highest weighting across the scenarios. Notably, proactive scenarios are more weighted toward "lack of technical expertise" (Scenario A-46.1\% and Scenario C - 55.7\%), while reactive scenarios are more weighted toward "lack of understanding" (Scenario B-34.3\% and Scenario D-33.2\%). Both these factors indicate that the training that service providers receive (if any) is insufficient to ensure preventative maintenance is conducted. There is a clear need to build capacity for continuous training and professionalized approaches to maintenance within service delivery, such as the efforts by practitioners outlined by Deal and Furey (2019) [39].

The proactive scenarios have a lower weighting related to a "lack of money" compared to the reactive scenarios, reinforcing how preventative approaches can reduce costs of premature failure. Findings by Olaerts et al. (2019) [40] indicate that water users value reliable and fast maintenance services compared to other unreliable improved sources. "Parts not available" was also highlighted as an issue in a small number of cases, as the spare parts and supply chains for service delivery can influence water point functionality [21,28,41-43]. A lack of understanding of the importance of financial resources and preventative maintenance can be further attributed to the inadequate training and support for service providers in the post-construction phase of rural water supply [44]. The result is service providers adopting an "if it isn't broken why fix it" approach and a decision to rely on external support for financial provision rather than self-reliance. When a community has the financial resources and technical expertise on hand, they are less reliant on such external support [13].

\subsection{Behaviors toward Major Repairs}

\subsubsection{Major Repairs during the Lifecycle}

Figures 2 and 3 outline major repairs conducted during the previous year under the different tariff scenarios for assets with no rehabilitation (new) and assets that have undergone rehabilitation. Figure 2 presents the costs of major repairs across the lifecycle for assets with no rehabilitation. The assets with no rehabilitation follow a notable trend across all scenarios. At the beginning of the lifecycle, costs tend to be $M W K<50,000$. The occurrences of these lower cost interventions decrease as assets age, and costlier major repairs are prevalent.

Over the lifecycle of Scenario A (tariffs collected each month), the increase in costs primarily consists of costs between MWK 50,000 and MWK 100,000. There are few occurrences above this across the lifecycle, with the exception of years toward the end of the lifecycle (years 12-13), indicating that routine maintenance is keeping the asset functioning. Scenario B (tariffs collected when repairs needed) presents a similar trend to Scenario A. However, there is a greater occurrence of lower cost major repairs in the earlier years of the lifecycle. This gradually increases to an order of MWK 50,000-100,000 between years 3 and 11. Scenario C (tariffs collected annually) shows more sporadic expenditure primarily within the lower two cost groups, MWK < 50,000 and MWK 50,000-100,000. In the years following installation (year 1-3), costs continue to be minimal (less intervention) at MWK $<50,000$. Post-year 3 after installation, there is an increase in costs primarily in the range of MWK 50,000-100,000 compared to the gradual increase in costs over the lifecycle displayed in Scenarios A and B. Scenario D (no managed tariff collection) presents higher costs overall than the previous three scenarios. Following year 1, the number of cases of costs of MWK < 50,000 drastically decreases (little or no preventative maintenance), resulting in a higher cost of repairs, primarily MWK 50,000-100,000 and MWK 100,000-150,000, across the lifecycle. 
Major repairs cost (MWK)

Percentage when no rehabilitation of the water point has taken place

\begin{tabular}{|c|c|c|c|c|c|c|c|c|c|c|c|c|c|c|c|}
\hline Scenario A (Year) & 1 & 2 & 3 & 4 & 5 & 6 & 7 & 8 & 9 & 10 & 11 & 12 & 13 & 14 & 15 \\
\hline$<50,000 \mathrm{MWK}$ & 86.1 & 69.1 & 60.5 & 66.7 & 62.1 & 60.5 & 56.1 & 46.9 & 47.3 & 52.3 & 60.0 & 46.3 & 28.1 & 31.6 & 36.7 \\
\hline $50,000-100,000 \mathrm{MWK}$ & 2.8 & 16.4 & 26.3 & 27.1 & 31.8 & 28.9 & 31.7 & 37.5 & 38.2 & 34.1 & 27.3 & 24.4 & 37.5 & 52.6 & 46.9 \\
\hline $100,000-150,000 \mathrm{MWK}$ & 0.0 & 9.1 & 5.3 & 6.3 & 4.5 & 10.5 & 7.3 & 6.3 & 5.5 & 2.3 & 3.6 & 7.3 & 12.5 & 10.5 & 10.2 \\
\hline $150,000-200,000 \mathrm{MWK}$ & 2.8 & 3.6 & 0.0 & 0.0 & 1.5 & 0.0 & 0.0 & 6.3 & 5.5 & 6.8 & 3.6 & 9.8 & 6.3 & 1.8 & 4.1 \\
\hline $200,000-300,000 \mathrm{MWK}$ & 2.8 & 0.0 & 5.3 & 0.0 & 0.0 & 0.0 & 4.9 & 3.1 & 0.0 & 4.5 & 1.8 & 4.9 & 6.3 & 1.8 & 0.0 \\
\hline $300,000-400,000 \mathrm{MWK}$ & 0.0 & 0.0 & 0.0 & 0.0 & 0.0 & 0.0 & 0.0 & 0.0 & 0.0 & 0.0 & 3.6 & 4.9 & 6.3 & 0.0 & 2.0 \\
\hline$>400,000 \mathrm{MWK}$ & 5.6 & 1.8 & 2.6 & 0.0 & 0.0 & 0.0 & 0.0 & 0.0 & 3.6 & 0.0 & 0.0 & 2.4 & 3.1 & 1.8 & 0.0 \\
\hline Scenario B (Year) & 1 & 2 & 3 & 4 & 5 & 6 & 7 & 8 & 9 & 10 & 11 & 12 & 13 & 14 & 15 \\
\hline$<50,000 \mathrm{MWK}$ & 100.0 & 91.1 & 81.8 & 75.0 & 69.6 & 64.3 & 52.2 & 47.6 & 59.4 & 35.3 & 25.0 & 53.1 & 50.0 & 69.2 & 63.9 \\
\hline $50,000-100,000 \mathrm{MWK}$ & 0.0 & 2.2 & 15.2 & 10.7 & 17.4 & 26.2 & 34.8 & 38.1 & 37.5 & 47.1 & 50.0 & 34.4 & 25.0 & 26.9 & 25.0 \\
\hline $100,000-150,000 \mathrm{MWK}$ & 0.0 & 2.2 & 0.0 & 3.6 & 4.3 & 7.1 & 8.7 & 4.8 & 0.0 & 5.9 & 10.0 & 6.3 & 13.9 & 3.8 & 5.6 \\
\hline $150,000-200,000 \mathrm{MWK}$ & 0.0 & 0.0 & 0.0 & 0.0 & 0.0 & 2.4 & 4.3 & 0.0 & 3.1 & 5.9 & 5.0 & 6.3 & 11.1 & 0.0 & 2.8 \\
\hline $200,000-300,000 \mathrm{MWK}$ & 0.0 & 0.0 & 0.0 & 3.6 & 4.3 & 0.0 & 0.0 & 4.8 & 0.0 & 5.9 & 0.0 & 0.0 & 0.0 & 0.0 & 2.8 \\
\hline $300,000-400,000 \mathrm{MWK}$ & 0.0 & 0.0 & 0.0 & 0.0 & 0.0 & 0.0 & 0.0 & 4.8 & 0.0 & 0.0 & 5.0 & 0.0 & 0.0 & 0.0 & 0.0 \\
\hline$>400,000 \mathrm{MWK}$ & 0.0 & 4.4 & 3.0 & 7.1 & 4.3 & 0.0 & 0.0 & 0.0 & 0.0 & 0.0 & 5.0 & 0.0 & 0.0 & 0.0 & 0.0 \\
\hline Scenario C (Year) & 1 & 2 & 3 & 4 & 5 & 6 & 7 & 8 & 9 & 10 & 11 & 12 & 13 & 14 & 15 \\
\hline$<50,000 \mathrm{MWK}$ & 66.7 & 85.7 & 90.0 & 62.5 & 33.3 & 52.4 & 57.1 & 40.0 & 50.0 & 43.8 & 64.7 & 45.5 & 29.2 & 38.9 & 50.0 \\
\hline $50,000-100,000 \mathrm{MWK}$ & 33.3 & 7.1 & 10.0 & 31.3 & 42.9 & 38.1 & 14.3 & 60.0 & 42.9 & 50.0 & 35.3 & 40.9 & 50.0 & 50.0 & 35.7 \\
\hline $100,000-150,000 \mathrm{MWK}$ & 0.0 & 0.0 & 0.0 & 6.3 & 19.0 & 4.8 & 28.6 & 0.0 & 7.1 & 6.3 & 0.0 & 4.5 & 16.7 & 11.1 & 14.3 \\
\hline $150,000-200,000 \mathrm{MWK}$ & 0.0 & 0.0 & 0.0 & 0.0 & 0.0 & 0.0 & 0.0 & 0.0 & 0.0 & 0.0 & 0.0 & 4.5 & 4.2 & 0.0 & 0.0 \\
\hline $200,000-300,000 \mathrm{MWK}$ & 0.0 & 0.0 & 0.0 & 0.0 & 0.0 & 0.0 & 0.0 & 0.0 & 0.0 & 0.0 & 0.0 & 0.0 & 0.0 & 0.0 & 0.0 \\
\hline $300,000-400,000 \mathrm{MWK}$ & 0.0 & 0.0 & 0.0 & 0.0 & 0.0 & 4.8 & 0.0 & 0.0 & 0.0 & 0.0 & 0.0 & 0.0 & 0.0 & 0.0 & 0.0 \\
\hline$>400,000 \mathrm{MWK}$ & 0.0 & 7.1 & 0.0 & 0.0 & 4.8 & 0.0 & 0.0 & 0.0 & 0.0 & 0.0 & 0.0 & 4.5 & 0.0 & 0.0 & 0.0 \\
\hline Scenario D (Year) & 1 & 2 & 3 & 4 & 5 & 6 & 7 & 8 & 9 & 10 & 11 & 12 & 13 & 14 & 15 \\
\hline$<50,000 \mathrm{MWK}$ & 100.0 & 50.0 & 33.3 & 30.0 & 16.7 & 33.3 & 42.9 & 36.4 & 52.6 & 12.5 & 38.5 & 25.9 & 38.5 & 30.8 & 29.4 \\
\hline $50,000-100,000 \mathrm{MWK}$ & 0.0 & 40.0 & 0.0 & 30.0 & 50.0 & 33.3 & 42.9 & 36.4 & 21.1 & 37.5 & 61.5 & 51.9 & 46.2 & 38.5 & 47.1 \\
\hline $100,000-150,000 \mathrm{MWK}$ & 0.0 & 0.0 & 33.3 & 30.0 & 33.3 & 22.2 & 7.1 & 9.1 & 10.5 & 50.0 & 0.0 & 7.4 & 15.4 & 30.8 & 5.9 \\
\hline $150,000-200,000 \mathrm{MWK}$ & 0.0 & 0.0 & 0.0 & 10.0 & 0.0 & 11.1 & 0.0 & 9.1 & 10.5 & 0.0 & 0.0 & 3.7 & 0.0 & 0.0 & 5.9 \\
\hline $200,000-300,000 \mathrm{MWK}$ & 0.0 & 0.0 & 33.3 & 0.0 & 0.0 & 0.0 & 0.0 & 9.1 & 5.3 & 0.0 & 0.0 & 3.7 & 0.0 & 0.0 & 0.0 \\
\hline $300,000-400,000 \mathrm{MWK}$ & 0.0 & 0.0 & 0.0 & 0.0 & 0.0 & 0.0 & 0.0 & 0.0 & 0.0 & 0.0 & 0.0 & 3.7 & 0.0 & 0.0 & 5.9 \\
\hline$>400,000 \mathrm{MWK}$ & 0.0 & 10.0 & 0.0 & 0.0 & 0.0 & 0.0 & 7.1 & 0.0 & 0.0 & 0.0 & 0.0 & 3.7 & 0.0 & 0.0 & 5.9 \\
\hline
\end{tabular}

Figure 2. Heat map showing the percentage of total major repairs according to costs within each scenario for assets with no rehabilitation.

Major repairs cost (MWK)

Percentage when rehabilitation of the water point has taken place

\begin{tabular}{|c|c|c|c|c|c|c|c|c|c|c|c|c|c|c|c|}
\hline Scenario A (Year) & 1 & 2 & 3 & 4 & 5 & 6 & 7 & 8 & 9 & 10 & 11 & 12 & 13 & 14 & 15 \\
\hline$<50,000 \mathrm{MWK}$ & 22.0 & 21.6 & 22.2 & 20.0 & 8.0 & 33.3 & 0.0 & 50.0 & 66.7 & 75.0 & 0.0 & 0.0 & 0.0 & 0.0 & \\
\hline $50,000-100,000 \mathrm{MWK}$ & 12.2 & 23.5 & 25.9 & 10.0 & 16.0 & 33.3 & 0.0 & 0.0 & 33.3 & 0.0 & 100.0 & 50.0 & 0.0 & 33.3 & \\
\hline $100,000-150,000 \mathrm{MWK}$ & 12.2 & 3.9 & 7.4 & 3.3 & 0.0 & 0.0 & 0.0 & 50.0 & 0.0 & 0.0 & 0.0 & 0.0 & 50.0 & 0.0 & \\
\hline $150,000-200,000 \mathrm{MWK}$ & 7.3 & 7.8 & 14.8 & 3.3 & 0.0 & 0.0 & 0.0 & 0.0 & 0.0 & 0.0 & 0.0 & 0.0 & 0.0 & 33.3 & \\
\hline 200,000 - 300,000 MWK & 9.8 & 5.9 & 3.7 & 0.0 & 8.0 & 0.0 & 0.0 & 0.0 & 0.0 & 0.0 & 0.0 & 0.0 & 50.0 & 0.0 & \\
\hline $300,000-400,000 \mathrm{MWK}$ & 19.5 & 9.8 & 7.4 & 16.7 & 4.0 & 0.0 & 0.0 & 0.0 & 0.0 & 0.0 & 0.0 & 0.0 & 0.0 & 0.0 & \\
\hline$>400,000 \mathrm{MWK}$ & 17.1 & 27.5 & 18.5 & 46.7 & 64.0 & 33.3 & 100.0 & 0.0 & 0.0 & 25.0 & 0.0 & 50.0 & 0.0 & 33.3 & \\
\hline Scenario B (Year) & 1 & 2 & 3 & 4 & 5 & 6 & 7 & 8 & 9 & 10 & 11 & 12 & 13 & 14 & 15 \\
\hline$<50,000 \mathrm{MWK}$ & 26.1 & 20.8 & 17.9 & 14.3 & 9.1 & 62.5 & 71.4 & & & & 50.0 & 33.3 & & & \\
\hline $50,000-100,000 \mathrm{MWK}$ & 13.0 & 20.8 & 21.4 & 0.0 & 36.4 & 25.0 & 14.3 & & & & 0.0 & 0.0 & & & \\
\hline $100,000-150,000 \mathrm{MWK}$ & 13.0 & 25.0 & 25.0 & 35.7 & 18.2 & 0.0 & 0.0 & & & & 0.0 & 0.0 & & & \\
\hline $150,000-200,000 \mathrm{MWK}$ & 4.3 & 10.4 & 7.1 & 14.3 & 9.1 & 0.0 & 0.0 & & & & 50.0 & 33.3 & & & \\
\hline $200,000-300,000 \mathrm{MWK}$ & 8.7 & 8.3 & 7.1 & 21.4 & 27.3 & 0.0 & 0.0 & & & & 0.0 & 0.0 & & & \\
\hline $300,000-400,000 \mathrm{MWK}$ & 8.7 & 4.2 & 7.1 & 7.1 & 0.0 & 0.0 & 14.3 & & & & 0.0 & 0.0 & & & \\
\hline$>400,000 \mathrm{MWK}$ & 26.1 & 10.4 & 14.3 & 7.1 & 0.0 & 12.5 & 0.0 & & & & 0.0 & 33.3 & & & \\
\hline Scenario C (Year) & 1 & 2 & 3 & 4 & 5 & 6 & 7 & 8 & 9 & 10 & 11 & 12 & 13 & 14 & 15 \\
\hline$<50,000 \mathrm{MWK}$ & 33.3 & 26.7 & 5.0 & 0.0 & 33.3 & 50.0 & 100.0 & 100.0 & 0.0 & 0.0 & & 0.0 & & 0.0 & \\
\hline $50,000-100,000 \mathrm{MWK}$ & 16.7 & 33.3 & 20.0 & 40.0 & 33.3 & 50.0 & 0.0 & 0.0 & 0.0 & 0.0 & & 0.0 & & 0.0 & \\
\hline $100,000-150,000 \mathrm{MWK}$ & 0.0 & 20.0 & 5.0 & 20.0 & 33.3 & 0.0 & 0.0 & 0.0 & 0.0 & 0.0 & & 0.0 & & 0.0 & \\
\hline $150,000-200,000 \mathrm{MWK}$ & 0.0 & 0.0 & 5.0 & 0.0 & 0.0 & 0.0 & 0.0 & 0.0 & 25.0 & 0.0 & & 0.0 & & 0.0 & \\
\hline $200,000-300,000 \mathrm{MWK}$ & 0.0 & 0.0 & 5.0 & 20.0 & 0.0 & 0.0 & 0.0 & 0.0 & 0.0 & 0.0 & & 0.0 & & 0.0 & \\
\hline $300,000-400,000 \mathrm{MWK}$ & 33.3 & 0.0 & 0.0 & 20.0 & 0.0 & 0.0 & 0.0 & 0.0 & 0.0 & 100.0 & & 0.0 & & 100.0 & \\
\hline$>400,000 \mathrm{MWK}$ & 16.7 & 20.0 & 60.0 & 0.0 & 0.0 & 0.0 & 0.0 & 0.0 & 75.0 & 0.0 & & 100.0 & & 0.0 & \\
\hline Scenario D (Year) & 1 & 2 & 3 & 4 & 5 & 6 & 7 & 8 & 9 & 10 & 11 & 12 & 13 & 14 & 15 \\
\hline$<50,000 \mathrm{MWK}$ & 10.0 & 12.5 & 20.0 & 20.0 & 28.6 & 20.0 & 50.0 & 50.0 & 100.0 & 0.0 & 0.0 & 0.0 & & & \\
\hline $50,000-100,000 \mathrm{MWK}$ & 10.0 & 18.8 & 0.0 & 60.0 & 14.3 & 60.0 & 50.0 & 50.0 & 0.0 & 100.0 & 0.0 & 50.0 & & & \\
\hline $100,000-150,000 \mathrm{MWK}$ & 40.0 & 25.0 & 0.0 & 0.0 & 14.3 & 20.0 & 0.0 & 0.0 & 0.0 & 0.0 & 0.0 & 0.0 & & & \\
\hline $150,000-200,000 \mathrm{MWK}$ & 0.0 & 12.5 & 0.0 & 0.0 & 0.0 & 0.0 & 0.0 & 0.0 & 0.0 & 0.0 & 0.0 & 0.0 & & & \\
\hline $200,000-300,000 \mathrm{MWK}$ & 10.0 & 0.0 & 0.0 & 0.0 & 28.6 & 0.0 & 0.0 & 0.0 & 0.0 & 0.0 & 0.0 & 0.0 & & & \\
\hline $300,000-400,000 \mathrm{MWK}$ & 0.0 & 6.3 & 60.0 & 0.0 & 0.0 & 0.0 & 0.0 & 0.0 & 0.0 & 0.0 & 100.0 & 50.0 & & & \\
\hline$>400,000 \mathrm{MWK}$ & 30.0 & 25.0 & 20.0 & 20.0 & 14.3 & 0.0 & 0.0 & 0.0 & 0.0 & 0.0 & 0.0 & 0.0 & & & \\
\hline
\end{tabular}

Figure 3. Heat map showing the percentage of total major repairs according to costs within each scenario for assets that have undergone rehabilitation. 
When rehabilitation (replacement of major parts) has been conducted on an asset, it is general practice to consider it the start of a new lifecycle period [18]. Unfortunately, true rehabilitation of the entire pump-borehole system is rarely undertaken (this would reset the system to an "as new" status). Rehabilitation (as practiced by replacing parts that are worn) results in a notable difference in major repair costs across the lifecycle of the assets. Figure 3 presents the costs of major repairs across the lifecycle for assets after rehabilitation (time reset to zero years). While assets that have undergone rehabilitation have a lower number of occurrences of major repairs across the lifecycle when compared to those with no rehabilitation (see Supplementary Materials for details of data), the majority of major repairs occur earlier in the design life. It should be noted that the data have few points greater than 20 years of age due to the vast increase in new borehole installations with Afridev pumps between 2000 and 2019. Rehabilitation typically occurs toward the end of the design life of 15 years (highlighting the majority of cases in the early years); however, premature rehabilitation due to improper O\&M is evident, as seen in Figure 3, toward the end of the time period.

The costs expressed across the lifecycle are significantly higher for un-rehabilitated assets. Scenario A presents the largest distribution of cases of major repairs costing MWK $>400,000$, in the majority of cases between years 1 and 6 . Scenario $C$ also presents an increase in cases of MWK $>400,000$ in the first three years, where the majority of major repairs occur over the lifecycle. The major repairs conducted in Scenario B are primarily expressed between years 1 and 7. During this period, there is a higher distribution of costs expressed when compared to Scenarios A and C. However, these costs are significantly higher than those for assets without rehabilitation conducted (Figure 1). Scenario D follows a similar pattern to Scenario B, although to a lesser extent, as fewer major repairs and a lower cost distribution were evident.

\subsubsection{Stakeholders Undertaking Major Repairs}

Over the course of the lifecycle, major repairs may not be conducted by the service providers responsible for the asset. Table 2 shows which stakeholders conducted major repairs (within 1 year) according to the cost of the repairs. In all four scenarios, $A$ to $D$, the costs of major repairs primarily falls within MWK < 50,000 and MWK 50,000-100,000. The highlighted CBM service providers (Water Point Committees (WPC), area mechanics, and community members) primarily conduct repairs within these two cost brackets. WPCs conduct a notably higher distribution of $\mathrm{MWK}<50,000$, with the exception of Scenario D.

This is due to the higher costs of major repairs occurring across the lifecycle. In all scenarios, a lower percentage of area mechanics conduct major repairs costing MWK $<50,000$, with larger distributions in the higher costs compared to WPCs. In Scenarios C and D, there is a larger number of community members in the MWK $<50,000$ group (likely as a cost-saving measure). In Scenarios A and B, there are fewer occurrences of community members conducting major repairs.

When considering costs above MWK 100,000, external stakeholders express a larger distribution in all of the scenarios. Local governments and private contractors lead/fund work across all costs; however, there are few occurrences of these stakeholders conducting major repairs in each of the scenarios. Notably, NGOs are the third most common stakeholder to conduct major repairs in all of the scenarios. NGO-led interventions are distributed across all costs, with the majority of occurrences in the higher range of costs. In all the scenarios, major repairs costing MWK >400,000 are most commonly undertaken by NGOs. 
Table 2. Stakeholders conducting major repairs by cost groups.

\begin{tabular}{|c|c|c|c|c|c|c|c|c|}
\hline \multirow{2}{*}{ Stakeholder } & \multicolumn{8}{|c|}{ Costs of Major Repairs-Thousands of MWK (\%) } \\
\hline & $n$ & $<50$ & 50-100 & 100-150 & 150-200 & $200-300$ & $300-400$ & $>400$ \\
\hline \multicolumn{9}{|c|}{ Scenario A } \\
\hline WPC & 343 & 72.9 & 23.0 & 2.3 & 1.5 & 0.0 & 0.0 & 0.3 \\
\hline Area Mechanic & 308 & 42.2 & 41.2 & 11.7 & 2.3 & 0.7 & 1.0 & 1.0 \\
\hline Community Members & 34 & 47.1 & 41.2 & 0.0 & 2.9 & 5.9 & 0.0 & 2.9 \\
\hline Local Government & 29 & 10.3 & 34.5 & 13.8 & 10.3 & 6.9 & 6.9 & 17.2 \\
\hline NGO & 124 & 5.7 & 8.9 & 4.8 & 9.7 & 10.5 & 16.1 & 44.4 \\
\hline Private Contractor & 34 & 11.8 & 32.4 & 2.9 & 17.7 & 11.8 & 5.9 & 17.7 \\
\hline WUA & 3 & 100.0 & 0.0 & 0.0 & 0.0 & 0.0 & 0.0 & 0.0 \\
\hline Other & 17 & 5.9 & 29.4 & 17.7 & 11.8 & 11.8 & 0.0 & 23.5 \\
\hline Don't Know & 2 & 0.0 & 0.0 & 0.0 & 0.0 & 0.0 & 50.0 & 50.0 \\
\hline Total & 894 & 46.3 & 28.8 & 6.5 & 4.0 & 2.8 & 3.1 & 8.5 \\
\hline \multicolumn{9}{|c|}{ Scenario B } \\
\hline WPC & 239 & 77.4 & 15.9 & 3.8 & 2.1 & 0.0 & 0.4 & 0.4 \\
\hline Area Mechanic & 223 & 46.2 & 32.3 & 11.7 & 4.9 & 4.0 & 0.0 & 0.9 \\
\hline Community Members & 20 & 35.0 & 30.0 & 30.0 & 0.0 & 5.0 & 0.0 & 0.0 \\
\hline Local Government & 5 & 0.0 & 40.0 & 20.0 & 20.0 & 0.0 & 0.0 & 20.0 \\
\hline NGO & 57 & 14.0 & 10.5 & 8.8 & 12.3 & 12.3 & 15.8 & 26.3 \\
\hline Private Contractor & 9 & 0.0 & 22.2 & 11.1 & 0.0 & 11.1 & 0.0 & 55.6 \\
\hline Other & 16 & 31.3 & 37.5 & 18.8 & 6.3 & 6.3 & 0.0 & 0.0 \\
\hline Don't Know & 3 & 33.3 & 33.3 & 0.0 & 0.0 & 0.0 & 0.0 & 33.3 \\
\hline Total & 572 & 54.0 & 23.3 & 8.9 & 4.4 & 3.3 & 1.8 & 4.4 \\
\hline \multicolumn{9}{|c|}{ Scenario C } \\
\hline WPC & 126 & 61.9 & 31.8 & 5.6 & 0.0 & 0.0 & 0.0 & 0.8 \\
\hline Area Mechanic & 99 & 38.4 & 50.5 & 9.1 & 1.0 & 0.0 & 0.0 & 1.0 \\
\hline Community Members & 10 & 70.0 & 10.0 & 10.0 & 0.0 & 10.0 & 0.0 & 0.0 \\
\hline Local Government & 8 & 12.5 & 50.0 & 12.5 & 12.5 & 0.0 & 0.0 & 12.5 \\
\hline NGO & 41 & 0.0 & 12.2 & 12.2 & 4.9 & 2.4 & 17.1 & 51.2 \\
\hline Private Contractor & 5 & 40.0 & 20.0 & 20.0 & 0.0 & 0.0 & 20.0 & 0.0 \\
\hline Other & 4 & 50.0 & 25.0 & 25.0 & 0.0 & 0.0 & 0.0 & 0.0 \\
\hline Total & 293 & 43.7 & 34.8 & 8.5 & 1.4 & 0.7 & 2.7 & 8.2 \\
\hline \multicolumn{9}{|c|}{ Scenario D } \\
\hline WPC & 78 & 44.9 & 41.0 & 10.3 & 1.3 & 1.3 & 0.0 & 1.3 \\
\hline Area Mechanic & 90 & 31.1 & 44.4 & 18.9 & 3.3 & 1.1 & 0.0 & 1.1 \\
\hline Community Members & 7 & 71.4 & 14.3 & 14.3 & 0.0 & 0.0 & 0.0 & 0.0 \\
\hline Local Government & 10 & 10.0 & 20.0 & 20.0 & 10.0 & 0.0 & 20.0 & 20.0 \\
\hline NGO & 27 & 0.0 & 14.8 & 25.9 & 7.4 & 11.1 & 14.8 & 25.9 \\
\hline Private Contractor & 6 & 16.7 & 33.3 & 0.0 & 0.0 & 0.0 & 16.7 & 33.3 \\
\hline Other & 15 & 26.7 & 33.3 & 0.0 & 13.3 & 13.3 & 6.7 & 6.7 \\
\hline Total & 233 & 31.8 & 36.9 & 15.0 & 3.9 & 3.0 & 3.4 & 6.0 \\
\hline
\end{tabular}

\subsubsection{Replacement of Components}

Of the major repairs that were undertaken within each scenario, the distribution of fast-wearing (typical lifecycle of 0-2 years) and longer-life components (typical lifecycle of 2-15 years depending on component) is presented in Figure 4, identified in Figure 1, and detailed information is available in the Supplementary Materials (Tables S1-S10). There are notable differences in the components replaced during major repairs for assets that have undergone rehabilitation and those that have not, indicating the impact that a rehabilitation exercise has on reducing future repairs.

In all scenarios, assets without rehabilitation have a lower rate of replacement of fast-wearing components. Scenarios A and C express a similar distribution of components replaced (i.e., $57.1 \%$ and $59.2 \%$ of fast-wearing components and $42.9 \%$ and $40.8 \%$ of longerlife components, respectively). Approximately two thirds of cases in Scenario B express 
a distribution toward fast-wearing components (65.4\%). Scenario D presents a narrower distribution, with $2.5 \%$ of cases weighted toward fast-wearing components.
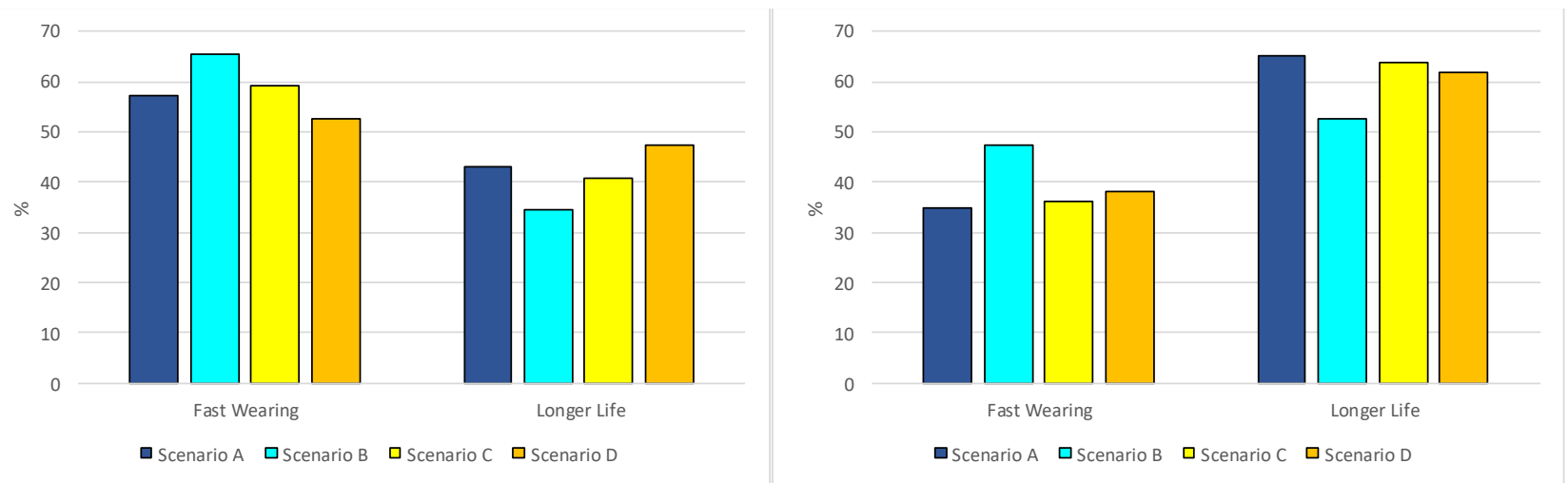

Figure 4. Distribution (\%) of total replacements by scenario for assets with no rehabilitation (left) and assets with rehabilitation (right) for each Scenario (A-D).

In all scenarios, assets with rehabilitation have a higher rate of replacement of longerlife components. Approximately two thirds of cases in Scenario A, with a regular monthly tariff, express a distribution toward longer-life components (65.3\%). Scenario $\mathrm{C}$ with an annual tariff and Scenario D with no tariff present a similar distribution toward longer-life components $(63.8 \%$ and $61.8 \%$, respectively). Scenario B, providing a tariff only when repairs are required, presents a narrow distribution between the two types of components, with a weighting of $2.5 \%$ toward longer-life components.

Of the fast-wearing components replaced when no rehabilitation has occurred, all scenarios follow a similar distribution for component replacement (Figure 5). The three most common components under the fast-wearing parts category are bush bearings, centralizers (where Scenario D presents a lower distribution compared to the other scenarios), and U-seals. Bobbins represent approximately $15 \%$ of fast-wearing components, while cup seals and O-rings represent between $10 \%$ and $15 \%$ of cases in all scenarios. Where assets have been rehabilitated, the majority of replacements follow a similar trend of between $15 \%$ and $20 \%$ of cases. Notably, there is an increase in O-ring replacements in all scenarios, an increase in cup-seal replacements concerning Scenarios A, B, and C (with a decrease in Scenario D), and a decrease in U-seal replacements (Scenarios A and C).

When considering longer-life components, the scenarios follow a similar distribution with the exception of a few components. For assets with no rehabilitation, the majority of replacements represent below $10 \%$ of cases present, with pedestals being the least replaced component. Notable replacements include sockets, which are replaced in a larger number of cases in Scenario B than in other scenarios, and foot valves, which require a larger distribution of replacements than the majority of other components. Assets postrehabilitation also represent the majority of cases below $10 \%$. Notably, there is an increase in cylinder replacements (Scenario B), a decrease in foot valve replacements (Scenarios A, C, and D) and a slight increase in pedestal replacements (Scenarios A, C, and D). Scenario B still includes a large proportion of socket replacements, although to a lesser extent than assets with no rehabilitation.

Notably, rods are the most common longer-life component replaced during a major repair exercise for assets with and without rehabilitation conducted. This is potentially attributed to the reality that multiple rods are installed (dependent on depth in water), and given that the strain of pumping is focused on rods, there is a greater potential for them to wear or break at different times throughout the lifecycle. The behaviors toward the replacement of this item differ depending on the tariff scenarios across the lifecycle. 

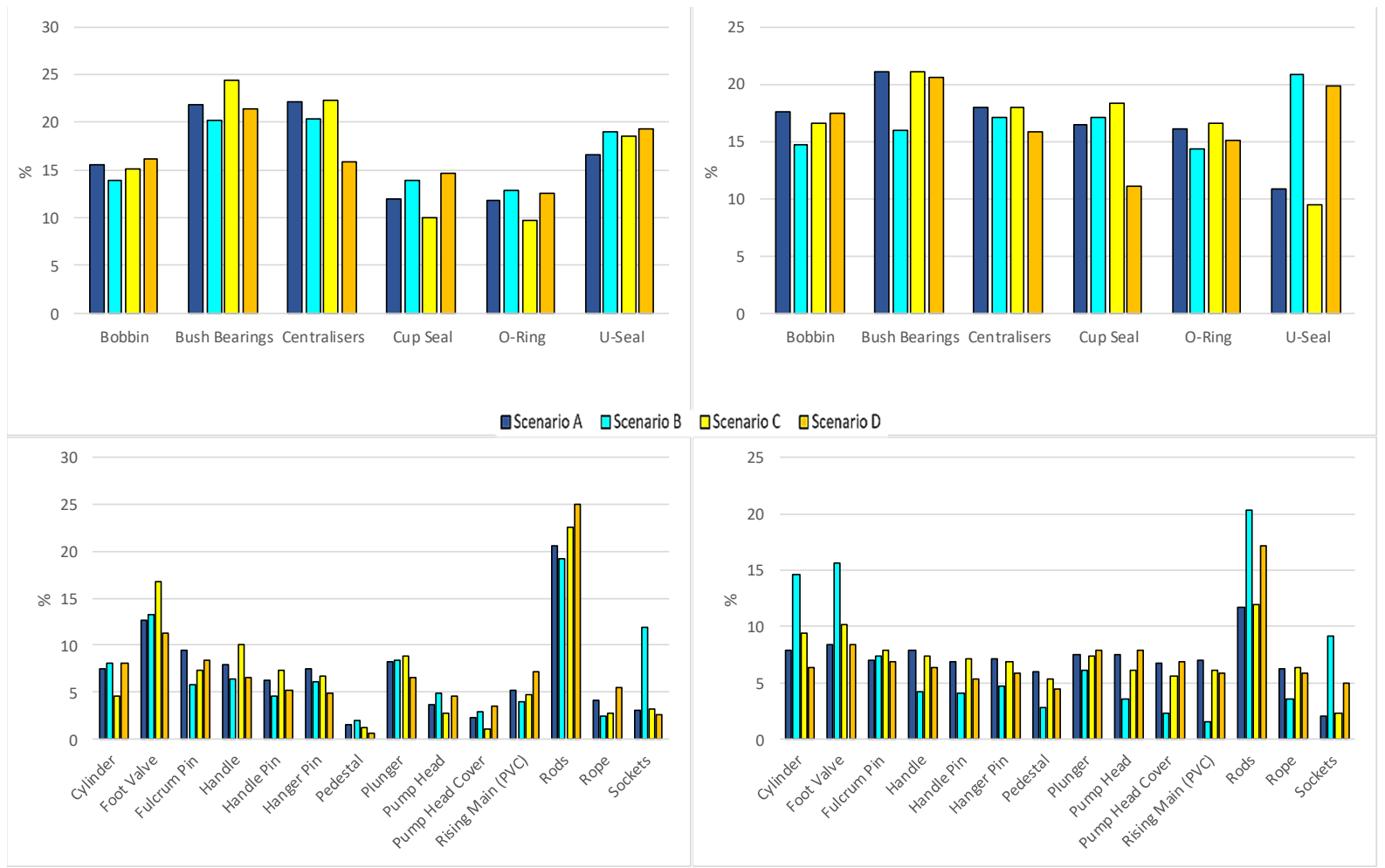

Figure 5. Distribution of fast-wearing (top) and of longer-life (bottom) components (noted on the $\mathrm{x}$ axis) by scenario for assets with no rehabilitation (left) and rehabilitation conducted (right) for each scenario (A-D).

\subsubsection{Replacement of Rods}

Within the Afridev handpump, rods have a typical lifecycle of 3-5 years before recommended replacement [38]. Rods are a costly component of Afridev maintenance, and the number of rods to be replaced varies depending on the depth of the borehole. The occurrences of rod replacements differ over the lifecycle in each scenario; however, there are notable trends. Figure 6 presents the time series of each scenario for replacing rods across the lifecycle of the Afridev when no rehabilitation has taken place. Figure 7 presents the time series of each scenario for replacing rods across the lifecycle of the Afridev when rehabilitation has been undertaken. The number of rods replaced in each year is highlighted (full data provided in Supplementary Material).

Scenario A presents a gradual increase in rod replacements between years 1 and 4 before reaching a peak in year $5(9.0 \%)$. This primarily consists of $1-2$ rod replacements per intervention. Following year 5 , there is a steep decline in replacements until year 7 . There is then a gradual increase in replacements toward the end of the Afridev lifecycle. The distribution in Scenario B presents a gradual rise in replacements between years 1 and 6 . This is followed by a consistent number of replacements between years 6 and 11; however, the number of rods replaced differs each year. There is a steep rise in replacements from year 11 before reaching its peak in year $13(9.6 \%)$. In the early years of the lifecycle under Scenario C, there are very few cases of rod replacements, while the later years represent the majority of cases. Between years 5 and 6 , there is a rise in replacements, before a steep decline in year 7 . There is a gradual rise in replacements between years 7 and 11 before greatly increasing in year 12 . The majority of replacements occur between years 12 and 13 (9.6\% and $12.6 \%$, respectively). There is a very low number of replacements occurring across the lifecycle of the Afridev under Scenario D, with a gradual increase in replacements across the lifecycle, with specific increases in years 2, 4, 9, and 12. 
Scenario A

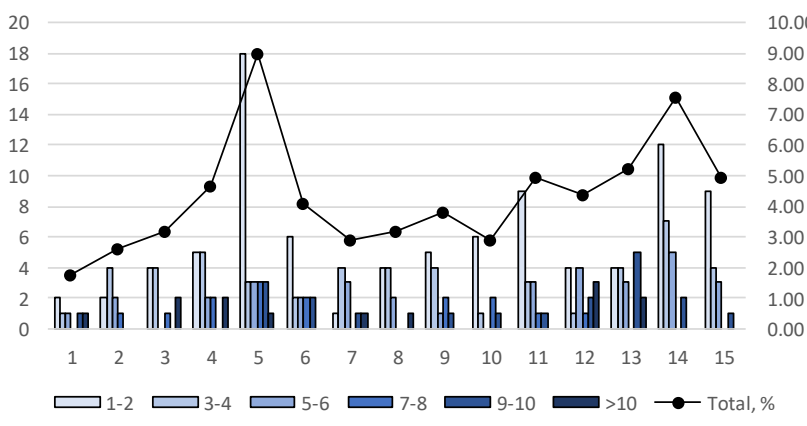

Scenario C

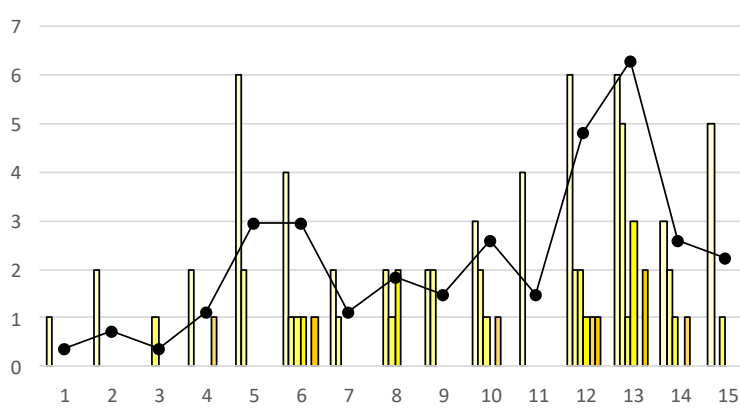

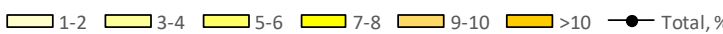

Scenario B

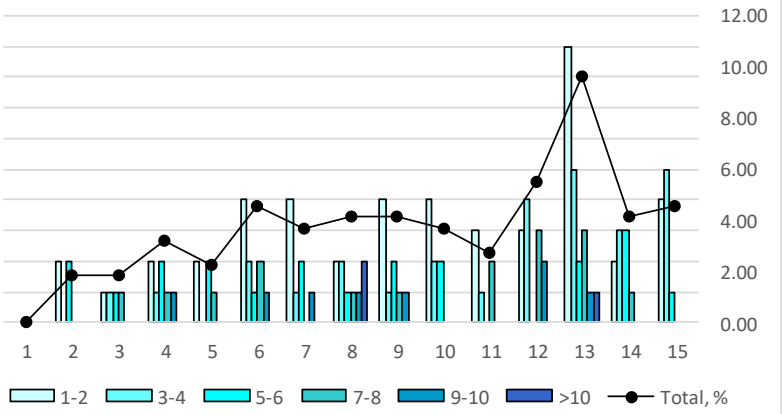

Scenario D

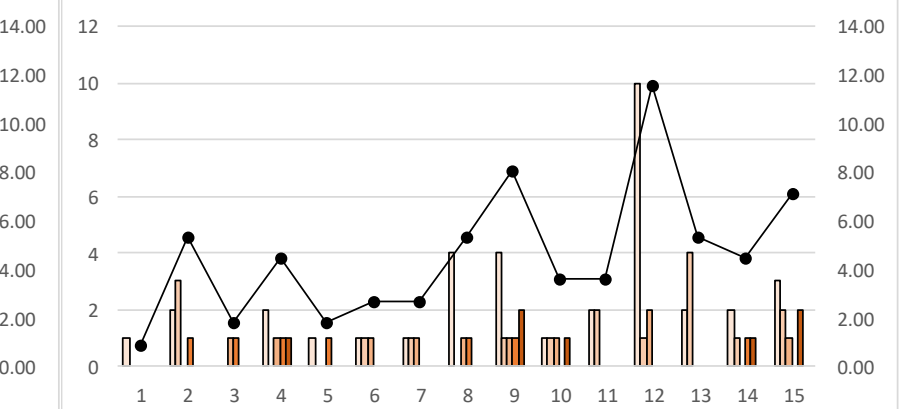

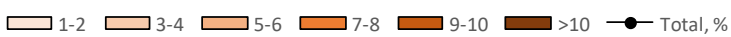

Figure 6. Number of rods (y axis) replaced across the $\mathrm{x}$ axis as time (years) in the lifecycle of the Afridev when water point has no rehabilitation.

Scenario A

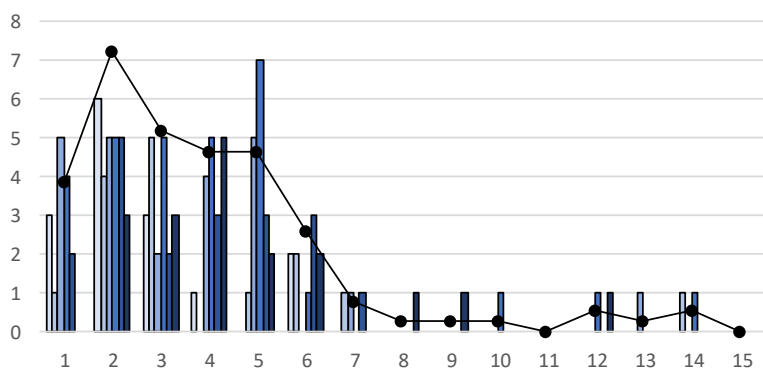

ए1-2

Scenario C

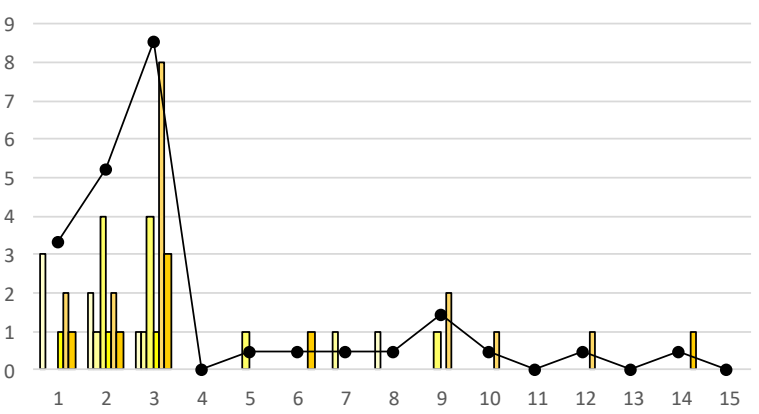

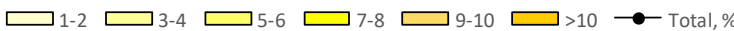

Scenario B

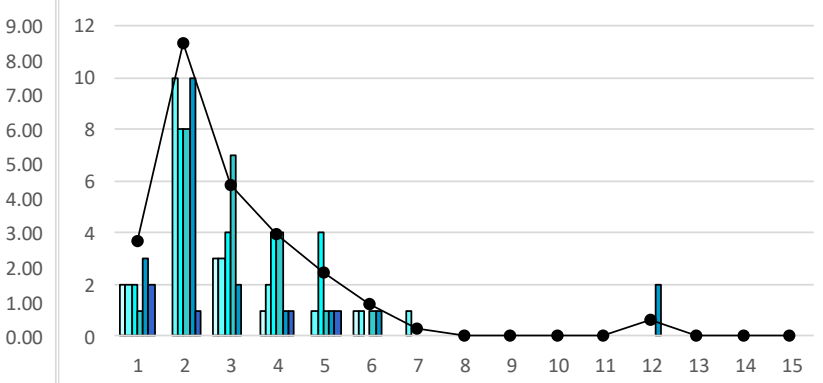

18.00

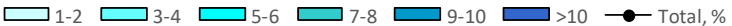

\section{Scenario D}

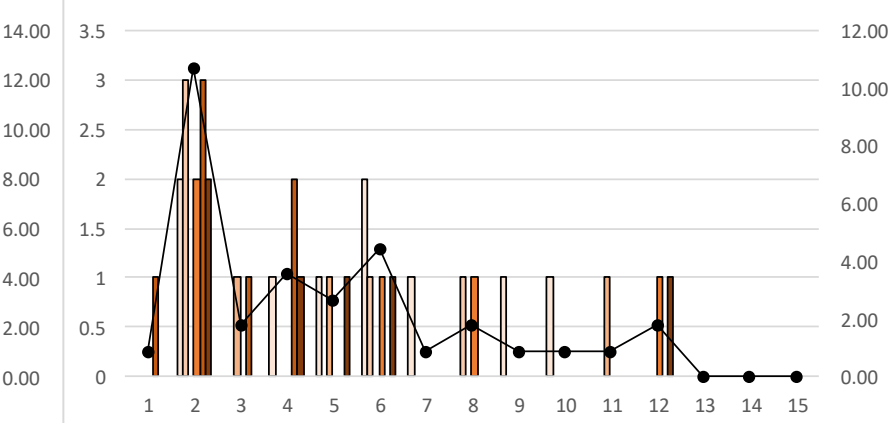

$\square$ 1-2

Figure 7. Number of rods replaced across the $\mathrm{x}$ axis as time (years) in the lifecycle of the Afridev when water point has undergone rehabilitation. 
The rod replacements for assets with rehabilitation present a similar trend over all scenarios. Each scenario presents replacements in the early years of the lifecycle before a decline in the later years. The number of larger groups of rods replaced is also significantly higher in these years compared to assets with no rehabilitation of the same year (Figure 6).

In Scenario A (after rehabilitation), the majority of replacements occur between years 1 and 5, with year 2 presenting the largest proportion of replacements $(8.1 \%)$. This is followed by a steep decline before limited replacements toward the end of the lifecycle. Scenario B also expresses a peak in year $2(17.0 \%)$ before a gradual decline in replacements between years 2 and 7 . Scenario $C$ presents an increase in the first three years of the lifecycle, reaching a peak in year $3(13.3 \%)$. This is followed by a steep decline and minor replacements over the rest of the lifecycle. Scenario D shows the lowest number of replacements, with replacements mainly occurring in year $2(10.7 \%)$, followed by a steep decline in year 3 . There is then a consistent number of replacements up to year 12 .

\section{Discussion}

\subsection{Tariff Impact on the Functionality of the Water Point Asset}

The recurrent design life and cost of each component can be used to determine the projected cumulative costs to keep the Afridev handpump fully operational. Figure 8 provides the routine (best case) cumulative costs for an Afridev over a 15-year period (MWK $\sim 700,000$ ), and projections based on the observed failure rate of parts in Malawi (worst-case cumulative costs) of MWK 1.2 million. The true functionality (ability to deliver water according to the design criteria of the Afridev) is a function of the operation of the pump, and a function of correct and professional drilling, testing, development, and installation of the borehole infrastructure. It is interesting to note in Kalin et al. (2019) [2] that a significant proportion of Afridev installations do not provide water at design specifications due to poor or improper borehole infrastructure [2,28]; therefore, the statistical dataset on handpump functionality in Malawi can never approach 100\% design functionality.

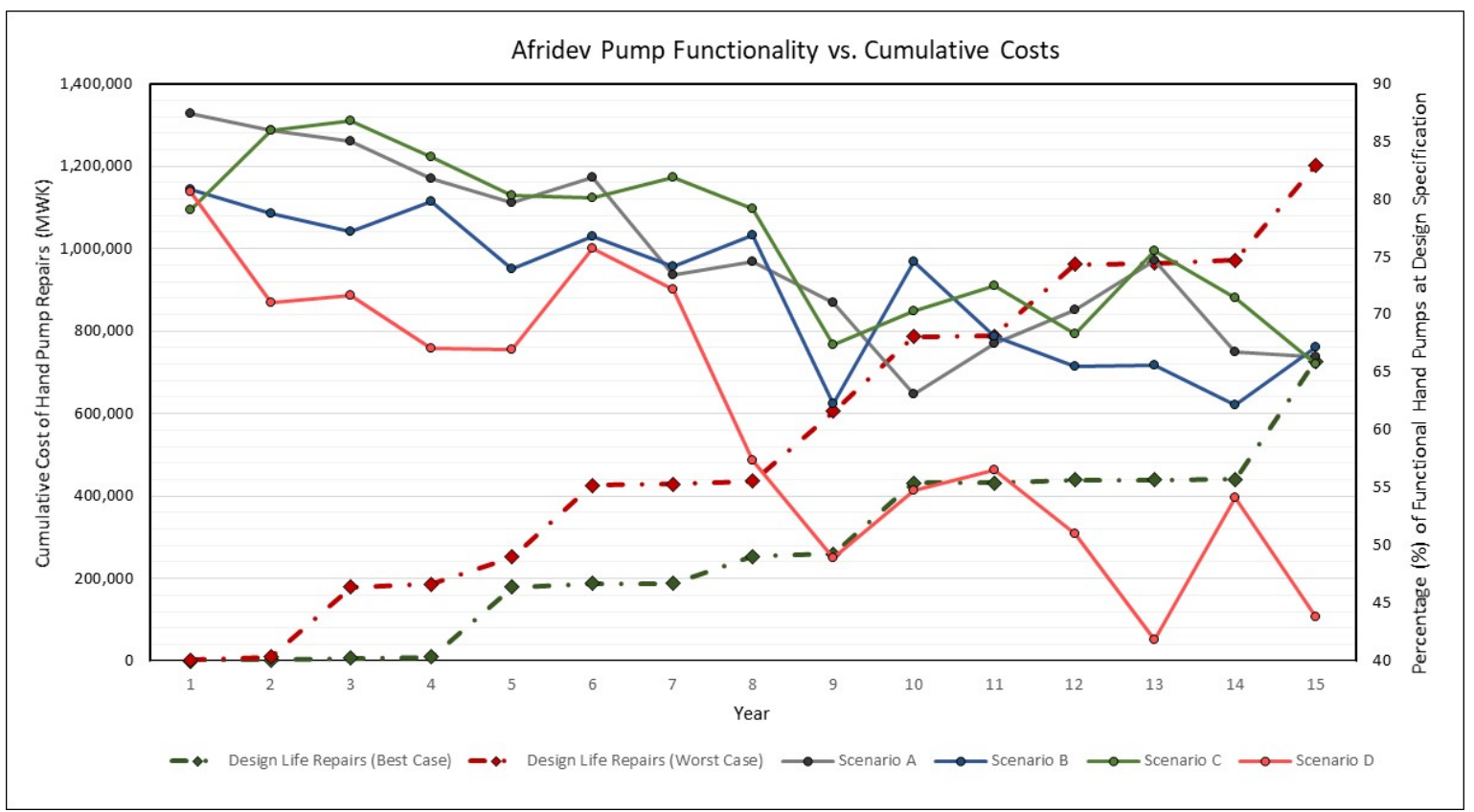

Figure 8. Projected range of cumulative costs for operation and management of Afridev water supplies, compared with the long-term functionality of the water supply over its 15-year design lifecycle (adapted from Truslove, et al., 2020 [28]).

The impact of the four tariff scenarios on the functionality of the water supply (age at time of measure) clearly shows that Scenarios A and C (recurrent managed tariff collection) result in the highest long-term functionality. The reactive tariff collection Scenario $B$ consistently had a $10 \%$ lower functionality, and Scenario D with no tariff planning con- 
sistently had an even lower (20\% to $30 \%)$ functionality rate. The planning and execution of tariff management is therefore critical to the ability of water point infrastructure to deliver service.

\subsection{Tariffs, Maintenance, and Rehabilitation}

In general, water supply asset management requires planning; therefore, Scenarios A (monthly tariff) and C (annual tariff), where tariffs are collected proactively for the maintenance and repairs of boreholes equipped with Afridev handpumps, are the preferable models for CBM. These produce annualized financial resources, and their proactive nature results in similar maintenance behaviors enhancing the continued serviceability of the water supply asset. In both scenarios, a large proportion declare that preventative maintenance is conducted at the site, which we attribute to the continued availability of financial resources to conduct such operations. The costs of major repairs under these scenarios further support the positive impact that available financial resources and preventative maintenance have on continued service. Across the lifecycle of the Afridev, the majority of costs fall into the MWK $<50,000$ and MWK 50,000-100,000 categories. CBM service providers primarily conduct these repairs, and external support (primarily NGOs) is favored for costlier categories (Table 2). This suggests that CBM service providers have the ability to conduct major repairs and replacements that maintain the lifecycle of the handpump before potential problems occur. This is highlighted by the results shown in Figure 4, where a greater proportion of longer-life components are replaced than those in Scenario B. In particular, the replacement of rods in the early years shows an increase before the end of the typical lifecycle of rods (3-5 years), which is typical of a preventative maintenance approach. However, as the costs of major repairs increase toward the end of the lifecycle, reliance on external (non-community-based) support becomes more apparent. While a proactive tariff approach results in a positive behavior toward major repairs, it does not remove the challenges of conducting such exercises.

In Scenario B, the reactive approach to tariff collection, results suggest different behaviors to the aforementioned proactive scenarios. The collection of tariffs when required for repairs is inherently reactive due to the infrequent and unpredictable nature of pump failures and results in a lower number of communities conducting preventive maintenance than for tariff Scenarios A and C. Interestingly, where no preventative maintenance is reported, $23.3 \%$ of cases cited "lack of money" as the cause. This reactive approach to tariff collection suggests that cheaper, fast-wearing components are targeted over longer-life components, reducing functionality or resulting in premature breakdown of the water supply. This observation is supported by previous work by the authors where a shortfall in financial resources was found to increase the likelihood of declining serviceability [28]. Figure 4 further shows that the majority of major repairs undertaken using reactive tariffs consist mainly of fast-wearing components $(65.4 \%)$, and for assets that have undergone rehabilitation, the margin between fast-wearing and longer-life components is significantly lower than in the other scenarios. This is further noted by the replacement of rods over the lifecycle of the Afridev (Figures 6 and 7), where the majority of rod replacements occur later in the lifecycle. Similar to Scenarios A and C, CBM service providers whose management style aligns with Scenario B mainly conduct repairs in the MWK $<50,000$ and MWK 50,000-100,000 categories, relying on external support for conducting repairs in the costlier categories. At the same time, there is an increase in the distribution of lower costs being borne by NGOs, as well. This suggests that unplanned tariff management increases dependency on external support in all ranges of repairs. Tariff collection when required for repairs does not guarantee sufficient financial resources and should be discouraged within CBM training.

Where no tariff is collected for O\&M (Scenario D), the behaviors and resulting major repairs significantly differ from those in the previous scenarios. While financial resources may be sourced by rural service providers from elsewhere, there are no declared financial resources for the O\&M related to the water supply assets. The impact is a significant 
proportion of cases where no preventative maintenance is conducted (Table $2-39.8 \%$ ), for $18.3 \%$ of which "lack of money" was declared as the explanation. The lack of financial resources to conduct vital O\&M risks a decline in serviceability [28], similar to the case in Scenario B. As a result, the costs of major repairs may significantly increase, as described in Figure 1. There is an increase in cases where major repairs costing MWK 100,000-150,000 occur and a decrease in repairs $\mathrm{MWK}<50,000$ across the lifecycle compared to the other scenarios. In Scenarios A, B, and C, WPC s have primarily conducted repairs costing MWK $<50,000(72.9 \%, 77.4 \%$, and $61.9 \%$ respectively). However, Scenario D shows WPCs are more distributed across the costs than in previous scenarios. Furthermore, external support (primarily NGOs) is distributed across the major repair costs, highlighting the reliance on these stakeholders to provide this service. The lack of preventative maintenance may also be attributed to the greater occurrence of longer-life components needing replacement during major repairs compared to the other scenarios (Figure 3). This highlights the impact that financial resources and preventative maintenance can have on future repairs required for continued functionality.

\subsection{Rehabilitation and Major Repairs}

Assets that have been rehabilitated have different costs and replacements when compared to assets that have had no rehabilitation. There are fewer major repairs for assets post-rehabilitation, with the majority occurring in the early years of the lifecycle in years 1-6 (Scenarios A and D), years 1-7 (Scenario B), and years 1-3 (Scenario C). During this time, costlier repairs emerge compared to those without rehabilitation. This suggests that while rehabilitation may be determined to be the start of a new service, the reality is that all components that are replaced under a rehabilitation exercise may require replacement soon after. This is reflected in the higher costs of major repairs post-rehabilitation that are inevitably conducted and borne by external stakeholders (Table 2). For the CBM (or any local) management strategy to be sustainable, the recovery of value (tariff) must be sufficient to cover all lifecycle and management costs, and it is clear from the results that the current CBM models in Malawi must be radically changed to meet sustainability targets.

The results also highlight that rehabilitation is treated as an exercise to bring an asset back to an operational capacity, rather than as a like-new service. This is only a temporary solution that does not support sustainable service delivery. In all scenarios, the replacement of longer-life components is favored more than that of fast-wearing components, as the latter risks the need for repeated intervention. As a result, substantially higher costs are involved from external sources. This further highlights the inability of revenue collection to be sufficient to purchase and replace longer-life components [13].

The issue of large, major repair costs that arise post-rehabilitation highlights the importance of establishing sustainable service delivery over solely reinstating water coverage. The short-term gains of rehabilitation overlook the lifecycle cost aspect required for sustainable services. In addition, the disregard for routine water quality testing and for rehabilitation of "below ground" hydrogeological infrastructure means there will always be a downward trend in rural water supply infrastructure under the current ethos. The embedded "coverage" attitude of NGOs, donors, and stakeholders is at fault, and there must be a shift toward supporting capacity building or parastatals for a service delivery approach to rural water supply. Policy and practitioners have a responsibility to consider what changes are needed to enhance the long-term impact of installation and rehabilitation exercises, particularly when repeated intervention is currently required to conduct costly major repairs post-"new service".

\subsection{Replacement of Rods}

Rods were found to be the most commonly replaced component for both assets with and without rehabilitation under all tariff scenarios. Proactive scenarios (primarily Scenario A) show an increase in the replacement of rods in the first instance, as shown by the increase in years 3-6. This is primarily conducted by CBM service providers. There is a 
consistent increase in rod replacements following a decline in year 6 that include larger groups of rod replacements. The replacements in the reactive scenario (Scenario B) suggest that collection "when required for repairs" is the standard due to the consistent and lower number of replacements across the lifecycle.

In all scenarios, there are smaller groups of rods replaced across the lifecycle, suggesting that while replacements can be financed, they may not reflect the full number of rods present. When considering the rod replacements in assets post-rehabilitation, there is a significant number of replacements that include large groups of rods replaced compared to assets that have not been rehabilitated. This is to be expected when considering the costs during this period, which are primarily covered by the aforementioned external support.

The number of rods replaced in each scenario suggests that replacements happen on a needs basis when CBM service providers find an issue. While proactive scenarios in un-rehabilitated assets have shown a greater affinity toward replacing rods than reactive scenarios, the smaller than needed groups of rods throughout highlight the challenge of financing CapManEx at the local level without external support.

\section{Conclusions}

If distributed short-lifecycle water supply technologies such as handpumps continue to be implemented, policy and practitioners must focus on renewed capacity building for maintenance models that consider the full lifecycle costs of assets. Construction, and notably rehabilitation, focuses financial planning on short-term coverage goals rather than sustainable systems to provide continued service delivery. A revised water policy for Malawi should include assessment (pump, borehole, water quality and management) and capacity building to ensure that cost recovery and maintenance approaches are capable of meeting the lifecycle requirements of assets.

Within the Malawi national budget and donor financial planning, CapManEx remains a challenge as costs are often neglected pre- and post-construction of water supply assets. This study provides insights and further evidence toward understanding the impact that CapManEx can have toward the sustainability and timely replacement of handpump components over the design life. While CapManEx is recognized as an overlooked cost, lack of initial capacity building has been identified as contributing through a lack of preventative maintenance behaviors. The occurrence of communities that collect "no tariff" (Scenario D) coupled with a significant lack of preventative maintenance further indicate poor capacity building in sustainable service delivery.

The incomplete rehabilitation of a water supply has a notable effect on the costs and components that are replaced. Rehabilitation should include complete replacement of the pump infrastructure along with borehole rehabilitation (airlifting to remove sediment and possible treatments to chemically remove clogging agents), which was found to be totally lacking. Rehabilitation in the form of major part replacements was considered the start of a new service, bringing systems back to an operational use, but did not result in the replacement of all significant components. Larger major repair costs were found to significantly increase post-rehabilitation. This included the increased need for replacement of longer-life components in all scenarios. Costly major repairs typically encompass longerlife components (such as foot valves, rising main sections, and rods) and are conducted by external stakeholders such as NGOs. Larger groups of rods are replaced post-rehabilitation when such costs for major repairs are significantly higher, contrary to replacements of lower costs in un-rehabilitated assets within the same timeframe. The results highlight that the current service delivery model for rural water supply in Malawi is unable to fully provide the necessary CapManEx that is crucial for continued service without support from external actors, and we recommend that a review of the Malawi Government's CBM policy implementation strategies be undertaken to develop the appropriate means to ensure the long-term sustainability of rural water infrastructure. 
Supplementary Materials: The following are available online at https:/ / www.mdpi.com/article/10 .3390/w13121666/s1. Table S1: Scenario A-Costs of major repairs distribution; Table S2: Scenario BCosts of major repairs distribution; Table S3: Scenario C-Costs of major repairs distribution; Table S4: Scenario D-Costs of major repairs distribution; Table S5: Distribution of component replacement for assets with no rehabilitation; Table S6: Distribution of component replacement for assets with rehabilitation; Table S7: Scenario A rod replacements; Table S8: Scenario B rod replacements; Table S9: Scenario C rod replacements; Table S10: Scenario D rod replacements.

Author Contributions: Conceptualization, J.P.T. and R.M.K.; methodology, J.P.T.; data curation, J.P.T. and R.M.K.; formal analysis, J.P.T.; writing, J.P.T. and R.M.K.; review and editing, R.M.K., J.P.T., E.M. and A.B.C.; visualization, J.P.T. and R.M.K.; supervision: R.M.K. and A.B.C. All authors have read and agreed to the published version of the manuscript.

Funding: We gratefully acknowledge the funding of this research by the Scottish Government under the Scottish Government Climate Justice Fund Water Futures Programme research grant HN-CJF-03 awarded to the University of Strathclyde (R.M. Kalin).

Institutional Review Board Statement: Not applicable.

Informed Consent Statement: Not applicable.

Data Availability Statement: Supplementary materials provides additional data used for this study.

Acknowledgments: We thank the Government of Malawi Ministry of Agriculture, Irrigation and Water Development (MoAIWD) for their continued direct collaboration, and implementation partners United Purpose, World Vision, CADECOM, CARE, BAWI, and Water for People for their support. In particular, the authors would like to thank BASEFlow for their ongoing technical and logistical support.

Conflicts of Interest: There are no conflicts of interest to declare.

\section{References}

1. Fonseca, C.; Franceys, R.; Batchelor, C.; McIntyre, P.; Klutse, A.; Komives, K.; Snehalatha, M. Life-cycle Costs Approach: Costing Sustainable Services. Available online: https://www.washcost.info/pubs (accessed on 4 October 2018).

2. Kalin, R.M.; Mwanamveka, J.; Coulson, A.B.; Robertson, D.J.; Clark, H.; Rathjen, J.; Rivett, M.O. Stranded Assets as a Key Concept to Guide Investment Strategies for Sustainable Development Goal 6. Water 2019, 11, 702. [CrossRef]

3. Mcintyre, P.; Casella, D.; Fonseca, C.; Burr, P. Supporting Water Sanitation and Hygiene Services for Life Priceless! Uncovering the Real Costs of Water and Sanitation. The Hague: IRC. Available online: https:/ / www.ircwash.org (accessed on 29 August 2018).

4. Martínez-Santos, P. Does 91\% of the world's population really have "sustainable access to safe drinking water"? Int. J. Water Resour. Dev. 2017, 33, 514-533. [CrossRef]

5. Huston, A.; Moriarty, P. Building Strong WASH Systems for the SDGs: Understanding the WASH System and Its Building Blocks. The Hague, the Netherlands. Available online: https:/ / www.ircwash.org/sites/default/ files/084-201813wp_buildingblocksdef_ web.pdf (accessed on 17 December 2018).

6. Truslove, J.P.; VM Miller, A.; Mannix, N.; Nhlema, M.; Rivett, M.O.; Coulson, A.B.; Kalin, R.M. Understanding the Functionality and Burden on Decentralised Rural Water Supply: Influence of Millennium Development Goal 7c Coverage Targets. Water 2019, 11, 494. [CrossRef]

7. Uandela, A.P.; Batchelor, C.; Reddy, R.; Mekala, S. WASHCost's Theory of Change: Reforms in the Water Sector and What They Mean for the Use of Unit Costs. Available online: https: / www.washcost.info (accessed on 29 August 2018).

8. RWSN Executive Steering Committee Myths of the Rural Water Supply Sector, RWSN Perspective No 4. St Gallen, Switzerland. Available online: https://www.ircwash.org/sites/default/files/RWSN-2010-Myths.pdf (accessed on 13 December 2017).

9. Reddy, V.R.; Batchelor, C. Cost of providing sustainable water, sanitation and hygiene (WASH) services: An initial assessment of a life-cycle cost approach (LCCA) in rural Andhra Pradesh, India. Water Policy 2012, 14, 409. [CrossRef]

10. Briscoe, J.; de Ferranti, D. Water for Rural Communities: Helping People Help Themselves; The World Bank: Washington, DC, USA, 1988.

11. van den Broek, M.; Brown, J. Blueprint for breakdown? Community Based Management of rural groundwater in Uganda. Geoforum 2015, 67, 51-63. [CrossRef]

12. Whaley, L.; Cleaver, F. Can "functionality" save the community management model of rural water supply? Water Resour. Rural. Dev. 2017, 9, 56-66. [CrossRef]

13. WaterAid Sustainability Framework. Available online: https://www.wateraid.org/publications (accessed on 29 August 2018).

14. Schouten, T.; Moriarty, P.B. Community Water, Community Management: From System to Service in Rural Areas; ITDG: London, UK, 2003; Available online: https://www.ircwash.org/resources/community-water-community-management-system-service-ruralareas (accessed on 5 June 2019). 
15. Harvey, P.A.; Reed, R.A. Sustainable supply chains for rural water supplies in Africa. In Proceedings of the Institution of Civil Engineers-Engineering Sustainability; Thomas Telford Ltd: London, UK, 2006; Volume 159, pp. 31-39. [CrossRef]

16. Morgan, P. Maintenance, the key to handpump survival. Waterlines 1993, 11, 2-4. [CrossRef]

17. Fonseca, C.; Smits, S.; Nyarko, K.; Naafs, A.; Franceys, R. Financing Capital Maintenance of Rural Water Supply Systems: Current Practices and Future Options. Available online: https:/ / www.washcost.info (accessed on 29 August 2018).

18. Franceys, R.; Pezon, C. Services are Forever: The Importance of Capital Maintenance (CapManEx) in Ensuring Sustainable WASH Services Briefing Note 1b. The Hague, The Netherlands. Available online: https://www.washcost.info/pubs (accessed on 7 January 2019).

19. Baumann, E. Do operation and maintenance pay? Waterlines 2006, 25, 10-12. [CrossRef]

20. Harvey, P.A.; Reed, R.A. Community-managed water supplies in Africa: Sustainable or dispensable? Community Dev. J. 2006, 42, 365-378. [CrossRef]

21. Foster, T. Predictors of Sustainability for Community-Managed Handpumps in Sub-Saharan Africa: Evidence from Liberia, Sierra Leone, and Uganda. Environ. Sci. Technol. 2013, 47, 12037-12046. [CrossRef]

22. Hutchings, P.; Chan, M.Y.; Cuadrado, L.; Ezbakhe, F.; Mesa, B.; Tamekawa, C.; Franceys, R. A systematic review of success factors in the community management of rural water supplies over the past 30 years. Water Policy 2015, 17, 963-983. [CrossRef]

23. Chowns, E. Is Community Management an Efficient and Effective Model of Public Service Delivery? Lessons from the Rural Water Supply Sector in Malawi. Public Adm. Dev. 2015, 35, 263-276. [CrossRef]

24. Etongo, D.; Fagan, G.; Kabonesa, C.; Asaba, B.R. Community-Managed Water Supply Systems in Rural Uganda: The Role of Participation and Capacity Development. Water 2018, 10, 1271. [CrossRef]

25. Kativhu, T.; Mazvimavi, D.; Tevera, D.; Nhapi, I. Implementation of Community Based Management (CBM) in Zimbabwe: The dichotomy of theory and practice and its influence on sustainability of rural water supply systems. Phys. Chem. Earth Parts A B C 2018, 106, 73-82. [CrossRef]

26. United Nations Sustainable Development Goal 6 Synthesis Report on Water and Sanitation; United Nations: New York, NY, USA, 2018.

27. Lockwood, H.; Smits, S. Supporting Rural Water Supply Moving towards a Service Delivery Approach; Practical Action Publishing Ltd.: Warwickshire, UK, 2011; Available online: http://www.rural-water-supply.net/_ressources /documents/default/1-419-21351158422.pdf (accessed on 29 August 2018).

28. Truslove, J.P.; Coulson, A.B.; Mbalame, E.; Kalin, R.M. Barriers to handpump serviceability in Malawi: Life-cycle costing for sustainable service delivery. Environ. Sci. Water Res. Technol. 2020, 6, 2138-2152. [CrossRef]

29. Truslove, J.P.; Coulson, A.B.; Nhlema, M.; Mbalame, E.; Kalin, R.M. Reflecting SDG 6.1 in Rural Water Supply Tariffs: Considering "Affordability" Versus "Operations and Maintenance Costs" in Malawi. Sustainability 2020, 12, 744. [CrossRef]

30. Geremew, M.; Tsehay, M. Using Evidence on Life Cycle Costs to Plan for Achieving the SDGs in Amhara, Ethiopia Paper for the WASH Systems Symposium. Available online: https:/ / www.ircwash.org/proceedings (accessed on 23 July 2019).

31. Back, J.O.; Rivett, M.O.; Hinz, L.B.; Mackay, N.; Wanangwa, G.J.; Phiri, O.L.; Kalin, R.M. Risk assessment to groundwater of pit latrine rural sanitation policy in developing country settings. Sci. Total. Environ. 2018, 613, 592-610, ISSN 0048-9697. [CrossRef]

32. Rivett, M.O.; Miller, A.V.; MacAllister, D.J.; Fallas, A.; Wanangwa, G.J.; Mleta, P.; Kalin, R.M. A conceptual model-based framework for pragmatic groundwater-quality monitoring network design in the developing world: Application to the Chikwawa District, Malawi. Groundw. Sustain. Dev. 2018, 6, 213-226. [CrossRef]

33. Rivett, M.O.; Robinson, H.L.; Wild, L.M.; Melville, J.; McGrath, L.; Phiri, P.; Kalin, R.M. Arsenic occurrence in Malawi groundwater. J. Appl. Sci. Environ. Manag. Afr. J. Online AJOL 2019, 22, 1807. [CrossRef]

34. Rivett, M.O.; Budimir, L.; Mannix, N.; Miller, A.V.; Addison, M.J.; Moyo, P.; Kalin, R.M. Responding to salinity in a rural African alluvial valley aquifer system: To boldly go beyond the world of hand-pumped groundwater supply? Sci.Total. Environ. 2019, 653, 1005-1024. [CrossRef]

35. Rivett, M.O.; Symon, S.; Jacobs, L.; Banda, L.C.; Wanangwa, G.J.; Robertson, D.J.; Kalin, R.M. Paleo-Geohydrology of Lake Chilwa, Malawi is the Source of Localised Groundwater Salinity and Rural Water Supply Challenges. Appl. Sci. 2020, 10, 6909. [CrossRef]

36. Addison, M.J.; Rivett, M.O.; Robinson, H.; Fraser, A.; Miller, A.M.; Phiri, P.; Kalin, R.M. Fluoride occurrence in the lower East African Rift System, Southern Malawi. Sci. Total. Environ. 2020, 712, 136260. [CrossRef] [PubMed]

37. Addison, M.J.; Rivett, M.O.; Phiri, O.L.; Milne, N.; Milne, V.; McMahon, A.D.; Kalin, R.M. Hidden Hot Springs as a Source of Groundwater Fluoride and Severe Dental Fluorosis in Malawi. Water 2021, 13, 1106. [CrossRef]

38. Erpf, K. Afridev: Installation and Maintenance Manual for the Afridev Handpump; Revision 2-2007; Rural Water Supply Network: St Gallen, Switzerland; Available online: http:/ / www.skat.ch (accessed on 24 January 2018).

39. Deal, P.T.; Furey, S. The 2019 RWSN Directory of Rural Water Supply Services, Tariffs, Management Models \& Lifecycle Costs. 2019th edn. RWSN. Available online: https://www.rural-water-supply.net/_ressources/documents/default/1-861-2-15681256 07.pdf (accessed on 10 September 2019).

40. Olaerts, L.; Walters, J.P.; Linden, K.G.; Javernick-Will, A.; Harvey, A. Factors Influencing Revenue Collection for Preventative Maintenance of Community Water Systems: A Fuzzy-Set Qualitative Comparative Analysis. Sustainability 2019, $11,3726$. [CrossRef]

41. Fisher, M.B.; Shields, K.F.; Chan, T.U.; Christenson, E.; Cronk, R.D.; Leker, H.; Bartram, J. Understanding handpump sustainability: Determinants of rural water source functionality in the Greater Afram Plains region of Ghana. Water Resour. Res. 2015, 51, 8431-8449. [CrossRef] 
42. Foster, T.; Willetts, J.; Lane, M.; Thomson, P.; Katuva, J.; Hope, R. Risk factors associated with rural water supply failure: A 30-year retrospective study of handpumps on the south coast of Kenya. Sci. Total. Environ. 2018, 626, 156-164. [CrossRef]

43. Moriarty, P.; Smits, S.; Butterworth, J.; Franceys, R. Trend in rural water supply: Towards a service delivery approach. Water Altern. 2013, 6, 329-349.

44. Baumann, E.; Furey, S. How Three Handpumps Revolutionised Rural Water Supplies A brief history of the India Mark II/III, Afridev and the Zimbabwe Bush Pump Rural Water Supply Network Field Note No 2013-1. St Gallen, Switzerland. Available online: http:/ / www.rural-water-supply.net (accessed on 7 February 2019). 